\title{
Problems and Prospects of Rotation of Pedagogical Staff in the Modern System of General Education in the Russian Federation
}

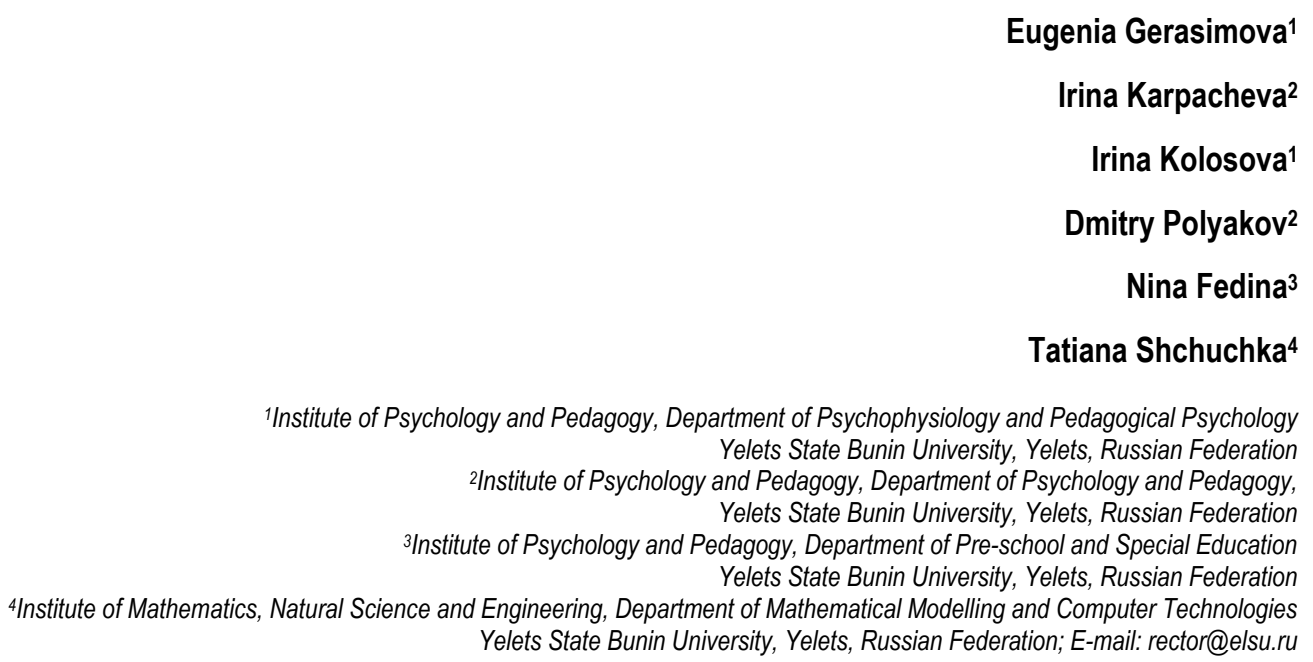

\section{Doi:10.5901/mjss.2015.v6n5s4p179}

\section{Abstract}

This article presents an analysis of the implementation of the technology of job rotation in the general education system of the Russian Federation. The objects of the analysis were the official websites of municipal and regional executive authorities in the education sector: regulatory legal documents, methodological and information materials, reflecting the creation and development of the personnel reserve in the general education system. The geographical scope of the analysis included all regions of the Russian Federation. The analysis covered the period of 2010-2015 years. The authors diagnosed the implementation of certain components of the technology of job rotation, and its unsystematic and declarative nature. The study found that the most promising model of personnel policy of the general education system in the Russian Federation is the consistent application of the technology of personnel reserve formation and job rotation. The main types of job rotation, which can be implemented in the management of the education system of the Russian Federation, include the rotation of heads of educational institutions of general education; vertical and horizontal rotation of pedagogical staff; rotation of young professionals and graduates of educational institutions of secondary vocational and higher education.

Keywords: general education system of the Russian Federation, rotation of heads of general educational institutions, vertical, horizontal rotation of the pedagogical staff, rotation of young specialists and graduates of educational institutions of secondary vocational and higher education, personnel reserve.

\section{Introduction}

\subsection{Introduction of the Problem}

The technology of job rotation is actively used in business and in public service. Organizations, using the technology of job rotation, position themselves as successful or innovative companies or as companies focused on growth and development. Often, job rotation is considered in the context of the technology of crisis management of an organization or a company. As a rule, a crisis manager is the initiator of these rotation acts. The application of the job rotation technology is capable to minimize the risk of a conflict of interests between the employee and the company, in which the personal interest (direct or indirect) of the employee affects or may affect the proper performance of their duties, and is capable of causing the damage to property and (or) business reputation. Also often, the technology of job rotation is used to solve the problem of rejuvenation of personnel, and recruitment and adaptation of promising graduates of institutions of 
secondary vocational and higher education.

As a rule, science differentiates the technologies of "ordinary" staff and management rotation. Rotation of directors is interpreted as follows: "In accordance with the articles of association of the majority of British companies, each year one third of company executives are required to resign, it usually happens at the annual general meeting. Thus, due to the rotation, the staying of any person as a director does not exceed three years. However, the outgoing director may be re-elected» (Business. Dictionary, 1998).

\subsection{Importance of the Problem}

The rotation of personnel in the general education system of the Russian Federation is a relatively new phenomenon, which is still of declarative nature. The scientific basis of this technology is almost completely absent at the presence of episodic practice considerably complicating its implementation. And specific application of the technology in the management of human resources of the general education in the Russian Federation is not defined, which induced the authors to focus on the following points.

Firstly, the system of general education is a budgetary sphere; therefore, some initial data, typical of the state of staffing in the commercial sector of the economy, is not typical of the public sector (for example, in terms of the requirements to the personnel, employees' preferences, etc.).

Secondly, the system of general education in the Russian Federation is quite a conservative system even within the budgetary sector of the economy. Its target and value orientations come into a conflict with certain essential characteristics of the technology of job rotation, which involve the notion of an effective, successful operation. According to Ushakov, the complexity of the application of the technology of job rotation in the general education system of the Russian Federation is caused by the fact that «there are no such precise success indicators like, for example, profit in business. There is no threat of bankruptcy, immediate closure of an organization if it is unsuccessful. In addition, there are social obligations in relation to educators and parents. Therefore, unsuccessful educational organizations exist long enough in this state» (Ushakov, 2010).

The Concept of Long-term Socioeconomic Development of the Russian Federation for the Period until 2020 emphasizes the relevance of the strategic goal of the state policy in the field of education-better accessibility of high quality education that meets the requirements of the innovative development of the economy, the contemporary needs of the society and every citizen. The formation of a new type of a manager-a manager of education; the implementation of age-specific rotation of the personnel, attraction of the new personnel and its consolidation in the education system are stated among others in the Concept's list of measures aimed at achieving the planned result. Accordingly, the implementation of effective personnel policies of the general education system in the Russian Federation through the introduction of human technologies, such as rotation, should be considered as a strategic activity that requires a comprehensive study, scientific justification, and testing.

Thus, the purpose of this article is to analyze the existing experience in job rotation in the general education system of the Russian Federation (2010-2015) within the context of critical and prospective approaches.

\subsection{Relevant Scholarship}

The technology of job rotation is widely and comprehensively developed in relation to the business area: Black, Lynch and Krivelyova (2004), Hsieh and Chao (2004), Jaturanonda, Nanthavanij and Chongphaisal (2006), Ortega (2001), Schultz, D. and Schultz, S.E. (2010). There are relatively a few works devoted to the study of application of the job rotation technology in general education, which indicates the novelty of this problem for the Russian science: Dmitriev (2012), Chechel (2014), Tanurkova (2014), Ushakov (2010).

\subsection{Statement of the Hypotheses and their Correspondence to Research Design}

As a working hypothesis of the study, we assumed that the current state of the technology of job rotation in the general education system of the Russian Federation could be regarded as implementation on the declarative level. The mechanisms for implementation of the technology of job rotation do not differ by its clarity, transparency, and consistency. In fact, they are not related to the mechanisms of implementation of the technology of personnel reserve. Obviously, this situation is caused by the sufficient degree of novelty and lack of scientific substantiation of this HR technology, including the specific application of the technology in the general education system of the Russian Federation. 


\section{Method}

\subsection{The Method of Statistical Survey}

The research program of studying the characteristics of rotation of pedagogical staff in general education included several basic steps:

definition of the conceptual foundations of rotation as the personnel technology;

definition of the main studied variables (rotation of heads of general educational institutions; vertical, horizontal rotation of pedagogical staff; rotation of young professionals and graduates; operational reserve; mechanisms to attract and stimulate the operational reserve);

- data collection, its quantitative and qualitative analysis.

\subsection{Methods of Analysis and Measurement}

The main method of research is the analysis of documents, in which the selected variables mentioned above were studied in the available online documents of various types: directives, orders, public reports; programs of development and upgrade of regional and municipal education systems for individual periods. According to the Federal Law of February 9, 2009 \#8-FZ "On ensuring access to information about the activities of state departments and local selfgovernment," regional and municipal executive authorities are obliged to publish information about their activities in mass media, including the Internet. Personnel maintenance is one of the main activities of regional and local organs of executive power in the sphere of education. Accordingly, the Internet must present information of all activities aimed at the development of system of personnel maintenance, including job rotation. The reasons for the lack of this information could be a lack of such activities, or failure to implement the above-mentioned law. In any case, the presence or absence of information about job rotation in the general education system may be an object of a quantitative and qualitative analysis.

\subsection{Description of the Study Sample}

The sample included all the regions of the Russian Federation, which were grouped by federal districts in the course of the quantitative analysis. The analysis was performed by the presence in the documentary sources of selected variables as a percentage in the district: availability of the operational personnel reserve; the work with the personnel reserve; the increase or decrease in the number of involved young specialists in educational institutions; the availability and types of the personnel work with the graduates of the institutions of secondary vocational and higher education, the social programs of different directions, designed for the work with young professionals and graduates of the institutions of secondary vocational and higher education.

The process of pedagogical personnel rotation in different regions is mainly represented by several kinds of documentary sources:

- programs, plans, and reports on the implementation of measures specified in the programs of activities for the period 2011-2020, such as: the long-term target program "Development of Education in the Republic of Bashkortostan for the period from 2013 to 2017"; the Section of the Program of social and economic development ("Development of Education") in the Udmurt Republic from 2015 to 2020; "On the results of the Ministry of Education of the Republic of Sakha (Yakutia) in 2013"; the "Work Plan of the Ministry of Education and Science of the Astrakhan Region in 2014," etc.;

- local sources of information, such as reports, resolutions and decisions of expert councils: the Report of the Kamchatka Krai "On the Results of the National Educational Initiative "Our New School 2011"'; the Draft Resolution of the August meeting of the pedagogical staff of the Altai Republic "The Main Directions and Objectives of the Education in the Altai Republic for the 2013-2014 Academic Year"; The Decision of the Expert Council of the Office of Educational Administration of Prokopyevsk dated 02.26.2015, etc.

\section{Results}

\subsection{Definition of the conceptual principles of rotation as $n$ HR technology}

Job rotation (from Latin Rotatio - "circular motion, rotation") is an HR technology based on the planned office relocation 
or substantial modification of job responsibilities of the employee.

The types of rotation are classified according to a number of attributes (the target, the direction, the term of movement, the path of motion, the level of specialization, mobility, functions). This information is summarized in Table 1.

Table 1. The types of job rotation

\begin{tabular}{|c|c|c|}
\hline Feature & Classification & Content \\
\hline \multirow[t]{7}{*}{ Target } & Leadership training & $\begin{array}{l}\text { Due to the search for perspective employees capable of effective management activities; } \\
\text { activation of service and professional advancement; rejuvenation of the managerial } \\
\text { personnel; It requires special training of the employee; associated with technology of } \\
\text { personnel reserve. }\end{array}$ \\
\hline & Change of work environment & $\begin{array}{l}\text { It is carried out within the horizontal rotation; prevents burnout of a specialist; it minimizes } \\
\text { the risk of a conflict of interest. }\end{array}$ \\
\hline & $\begin{array}{l}\text { Dissemination of experience of } \\
\text { effective management }\end{array}$ & $\begin{array}{l}\text { It assumes a transition of an effective manager to another organization having the worst } \\
\text { quality characteristics, in order to bring it to a state of sustainable development. }\end{array}$ \\
\hline & Involving young specialists & $\begin{array}{l}\text { It is due to the need to address the problem of rejuvenating the organization's human } \\
\text { resource (recruitment), as well as the search for promising professionals (headhunting); it } \\
\text { requires the application of learning technologies in the workplace; associated with } \\
\text { technology of personnel reserve. }\end{array}$ \\
\hline & $\begin{array}{l}\text { Preventing or stopping conflicts } \\
\text { between employees }\end{array}$ & $\begin{array}{l}\text { It is applied when a possible conflict between employees is chalked out within the division } \\
\text { of the organization that can potentially affect the quality and efficiency of work. }\end{array}$ \\
\hline & Providing interchangeability & $\begin{array}{l}\text { It is due to the need to maintain the health system in case of temporary employee } \\
\text { elimination (due to illness, vacation, training, etc.). }\end{array}$ \\
\hline & $\begin{array}{l}\text { Searching a more suitable } \\
\text { position for an employee }\end{array}$ & $\begin{array}{l}\text { It is applicable in case if you want to find a more suitable position for potentially efficient } \\
\text { staff at the unsatisfactory results in the previous one. }\end{array}$ \\
\hline \multirow[t]{2}{*}{ Direction of motion } & Vertical & $\begin{array}{l}\text { Promotion of an employee, which requires the development by the employee of new } \\
\text { professional competencies, social role; ensures the growth of professional motivation of } \\
\text { the employee; and is associated with the technology of personnel reserve. }\end{array}$ \\
\hline & Horizontal & $\begin{array}{l}\text { Transfer of an employee to a new position that promotes the professional development of } \\
\text { the employee by moving or changing his/her duties. }\end{array}$ \\
\hline \multirow[t]{2}{*}{ Term of movement } & Long-term & $\begin{array}{l}\text { Moving an employee to a new position for a year or more; it is accompanied by the } \\
\text { transfer of valuable experience that the employee has, and is considered as a measure of } \\
\text { crisis management. }\end{array}$ \\
\hline & Short-term & $\begin{array}{l}\text { Changing an employee's office for one or more days, months (duty cycle organization, } \\
\text { structural subdivision); is used in internships, promotes professional mobility of workers; } \\
\text { is associated with the acquisition or distribution of valuable experience. }\end{array}$ \\
\hline \multirow[t]{3}{*}{ Trajectory of motion } & Annular & $\begin{array}{l}\text { An employee changing positions returns to the starting position; it is used to enrich the } \\
\text { employee's valuable experience by the development of his/her professional mobility. }\end{array}$ \\
\hline & Irrevocable & $\begin{array}{l}\text { The employee moves to a new position without returning to the old one; it is used for } \\
\text { career development, in the propagation experience of effective management; at the } \\
\text { professional adaptation of young specialists. }\end{array}$ \\
\hline & Castling & $\begin{array}{l}\text { Swapping two employees of the same position; It is used to prevent professional burnout, } \\
\text { and promotes anti-corruption, nepotism in the professional relationships. }\end{array}$ \\
\hline \multirow[t]{3}{*}{ Level of specialization } & Another specialty & It is used to increase the versatility of employees. \\
\hline & Adjacent specialty & $\begin{array}{l}\text { It is used to develop the professional competencies of employees, to increase the } \\
\text { occupational mobility. }\end{array}$ \\
\hline & $\begin{array}{l}\text { Change of the nature of work, } \\
\text { while maintaining the existing } \\
\text { specialty }\end{array}$ & $\begin{array}{l}\text { It is used to develop the professional competencies of employees, to improve } \\
\text { professional mobility due to the prevention of occupational burnout of employees. }\end{array}$ \\
\hline \multirow[t]{2}{*}{ Level of mobility } & Intraorganizational & An employee changes his/her position within an organization or the same department. \\
\hline & Interorganizational & $\begin{array}{l}\text { An employee changes his/her position between the organizations, departments, } \\
\text { agencies. }\end{array}$ \\
\hline \multirow[t]{2}{*}{ Functions } & Organizational & $\begin{array}{l}\text { The rotation is aimed at improving the efficiency of the human resources usage in the } \\
\text { organization. }\end{array}$ \\
\hline & Motivational & The rotation is caused by the needs of employees. \\
\hline
\end{tabular}

The technology of job rotation involves technology of personnel reserve. As a rule, the personnel reserve is a specially selected group of employees of the organization with the aim of the perspective vertical (more rarely-horizontal) rotation for the formation and development of the administrative body of the organization. In fact, the technology of job rotation acts as the logical culmination of technology of personnel reserve. On the one hand, job rotation formed without a personnel reserve is unsystematic and sporadic. On the other, formation of personnel reserve without further rotation of personnel is incomplete, formalized by staff and management solutions, which are not able to lead the organization towards a sustainable effective activity. 


\subsection{Definition of the main studied variables of application of the job rotation technology in the general education system of the Russian Federation.}

The general education system of the Russian Federation can apply the following types of job rotation: rotation of heads of general educational institutions; vertical, horizontal rotation of pedagogical staff; rotation of young professionals and graduates.

Rotation of the heads of general educational institutions is a systematic job castling or promotion in the director post of the school for disseminating the experience of effective management of the educational organization. At the heart of this technology is the concept, according to which positive experience in management of an educational organization cannot be replicated, and only the leader personally can introduce it, after he has achieved some success in the management of the school. In this case, the principal performs the role of a crisis manager. The traversing speed in the conditions of the technology application to rotation of principals is 3 to 5 years. Many states of the European Union, particularly France, have this experience of management of the education system, in which the principal changes job every five years according to the contract (the Ministry of Education takes care of the financial aspect). Of course, the creation of an operational personnel reserve of heads of educational institutions precedes the launch of the rotation mechanism.

Vertical rotation of pedagogical workers is the systematic promotion of the teaching staff to management positions, as well as the systematic promotion in the post within a given cluster. The application of the vertical rotation technology is also associated with the creation of a personnel reserve of the general education system, with the improvement of professional competence of the pedagogical staff who are included in the personnel reserve.

Horizontal rotation of pedagogical workers is the systematic castling of staff that constitutes the management body of a general educational organization in order to prevent the burnout of specialists, to provide for improvement of their new professional competences and social roles of professional mobility. The technology of training at the workplace is the leading mechanism for horizontal rotation of teachers.

Rotation of young professionals and university graduates is a systematic job transfer of young specialists (in the case of graduates of secondary vocational and higher education, we are talking about the internship) to support their career start and growth and, as a consequence, professional motivation. Young professionals are the pedagogical workers who have the experience of professional work up to three years. Rotation of young specialists and graduates also requires prior establishment of the operational personnel reserve and involvement of recruitment mechanisms.

\subsection{Quantitative and qualitative analysis of data}

Certainly, job transfer and change in the job responsibilities of leaders and workers of the general education of the Russian Federation are consistently implemented in practice. However, the technology of the personnel reserve formation involves namely systematic job transfer or significant changes in job duties of both heads of educational organizations and pedagogical staff. Rotation technology of pedagogical staff defines the personnel policy of regions in the sphere of general education. Application of this technology is a sign of the developing organization, seeking a qualitative growth and functioning based on innovative achievements. Furthermore, the openness of the use of rotation technologies among the teaching staff makes management decisions transparent and thus, the motivation of pedagogical staff for career growth is carried out. Consequently, the transparency and accessibility of structure information, mechanisms and quality of implementation of this technology is the evidence of use of job rotation.

As was already mentioned, the technologies of personnel reserve formation and rotations are associated with each other and complement each other. In fact, the stage of implementation of these personnel technologies in a simplified version should be the following:

1. Conducting public tenders for the inclusion in the personnel reserve of managers of educational organizations and leadership of schools.

2. Formation of a personnel reserve by regional and municipal executive authorities in the field of education.

3. Implementation of well-planned work with the personnel reserve.

4. Rotation of the pedagogical personnel in accordance with the developed rotary strategy.

Based on these steps, the authors traced the implementation of these personnel technologies in the Russian Federation, the results of which are shown in Figure 1. 


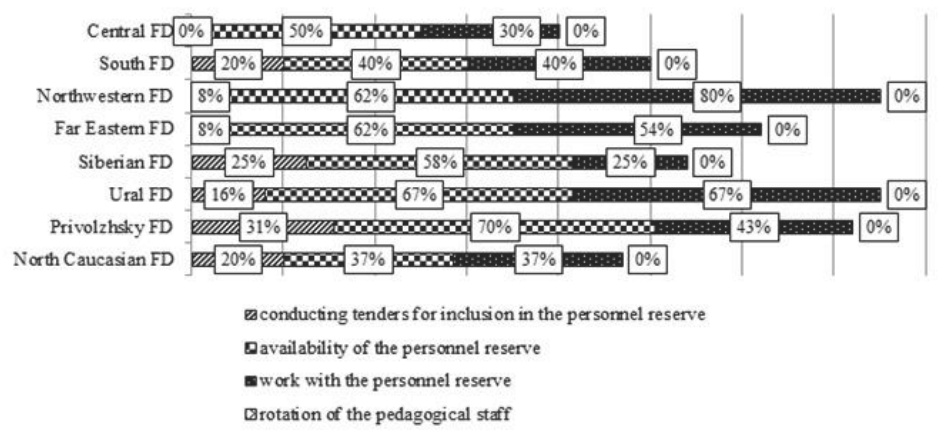

Figure 1: Application of the technology of the personnel reserve formation and job rotation in the general education system in the federal districts of the Russian Federation.

As seen in Figure 1, the regional and municipal executive authorities of education are in need for such stages of the analyzed personnel technologies as (2) the formation of the personnel reserve and (3) work with the personnel reserve.

Thus, the availability of the personnel reserve (2) is detected in more than half of the regions in the federal districts (the average value is 56\%). The Privolzhsky Federal District has the largest personnel reserve (70\%), as well as the Ural Federal District (67\%). The work on the formation of the personnel reserve is rather poorly conducted in the North Caucasian Federal District (37\%) and the Southern Federal District (40\%).

Information about the work with the personnel reserve (3) is presented on less than half of the official Internet portals of regions of the federal districts (the average value is $47 \%$ ). Leaders in the work with the personnel reserve are the Northwestern Federal District (80\%) and the Ural Federal District (67\%). Problems in the work with the personnel reserve are noticed in the following federal districts: the Siberian (25\%), Central (30\%), and North Caucasian (37\%) Federal Districts.

Almost all programs of the personnel reserve development are focused on the management body of the general education system. Only in certain regions of the Central Federal District (the Voronezh, Ryazan, and Tula Regions) and in the Northwestern Federal District (the Arkhangelsk and Murmansk Regions), we can notice the initiatives regarding the formation of the bank of vacancies, which include not only managerial jobs.

The fact that the work is done with all the established personnel reserve associations (both values are equal) is observed in such federal districts, as the Southern, Ural, and North Caucasian Federal Districts. Quite an interesting situation is found in the Northwestern Federal District: information about the work with the personnel reserve (80\%) has been provided more than there are promulgated established personnel reserve associations (62\%).

Such a stage of the analyzed personnel technologies as (1) conducting open tenders for the inclusion in the personnel reserve of heads of educational organizations and leadership of schools are in the least demand of the regional and municipal executive authorities in the field of education.

The availability of information on tenders for the inclusion in the personnel reserve (1) is present on websites of $16 \%$ of the regions in Federal Districts on the average. This work is conducted most actively in the Privolzhsky (31\%), Siberian (25\%), North-Caucasian (20\%), and Southern (20\%) Federal Districts. This work has not been promulgated or is very poorly represented in the Central (0\%), North-West (8\%), and Far Eastern (8\%) Federal Districts.

The fact that step (1), which is represented in the work of the minority of regional and municipal executive authorities in the education sphere, indicates the declarative approach of the majority subjects of the Russian Federation to implementation of the technologies of personnel reserve formation and job rotation. In fact, it demonstrates the formal implementation of these technologies, i.e. the results of their implementation exist only "on paper."

It is also alarming that there is no open evidence of engaging the rotary mechanisms (4) in the practice of the personnel policy in the general education system in the Russian Federation regions. This means that the functioning of the personnel reserve in the general education system does not have any results. Consequently, these data can be interpreted in two ways: either there are no results of the HR policy prescribed by the Ministry of Education to the Russian Federation regions in the sphere of education, or regional and municipal executive authorities in the spheres of education and HR policy are only in the phase of formation and understanding of the HR technology. In any case, the unsystematic, sporadic rotation of heads of general educational institutions is detected, as well as vertical and horizontal rotation of the 
pedagogical staff.

The authors consider the rotation of young specialists and graduates of institutions of secondary vocational and higher education as another indicator of the efficiency of personnel policy in the general education system of the Russian Federation. The quantitative data on this indicator are presented in Figure 2.

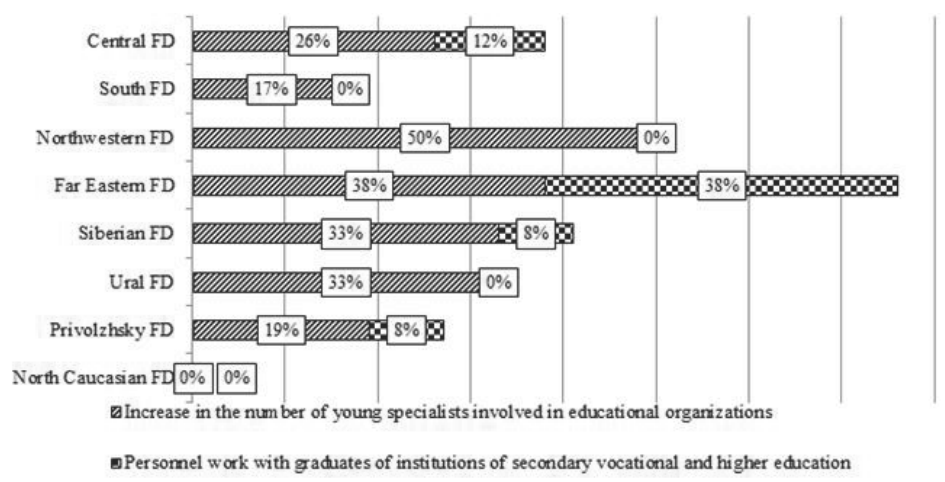

Figure 2. Personnel work with young specialists of education and graduates of institutions of secondary vocational and higher education in the federal districts of Russia.

As seen in Figure 2, the number of young professionals involved in educational organizations has increased in the average in $27 \%$ of the regions of the Russian Federation. The leaders here are the Northwestern Federal District (50\%) and the Far Eastern Federal District (38\%). There is no influx of young professionals in the North Caucasian Federal District (0\%), and this activity is the rather poorly implemented in the South (17\%) and Privolzhsky (19\%) districts. Personnel work with the graduates of educational institutions of secondary vocational and higher education is a kind of pedagogical staff rotation, which is just being implemented by the general education system of the Russian Federation. The leader in this regard is the Far Eastern Federal District (38\%). A number of federal districts show zero progress in this type of personnel work, like the South, Northwestern, Ural, and North Caucasian Federal Districts. Minor work in this direction is carried out in the Central Federal District (12\%), as well as in the Siberian (8\%) and in Privolzhsky (8\%) Federal Districts.

Also, an analysis of mechanisms was conducted to attract graduates into the general education system of the Russian Federation. We understand the mechanisms of attraction and stimulation of the operational reserve as any social or professional programs focused on attracting graduates into educational institutions and retention of young specialists in the general education system.

Mechanisms to attract graduates of secondary vocational and higher education into the general education system include several types of personnel work:

- material and social (targeted training, including the payment of scholarships and social guarantees to graduates, one-time cash payments, additional payments to specialists who have graduated with honors)

- the socially oriented type-competitive selection of candidates for work at educational institutions.

Social programs, aimed at enhancing the motivation of already working young professionals, represent two main types of incentives:

- financial and material incentives (lifting payment and securing a monthly payment of allowances to the basic salary of the young specialists for the first three years, one-time cash payments, grants);

- housing and material incentives (primary financial support for young staff-for purchasing (or construction) of individual property; reimbursement for housing lease, subsidizing for down payment on mortgage loans for the young, who are under the age of 35 years).

Figure 3 presents the social programs aimed at involvement of graduates of secondary vocational and higher education into the general education system of the Russian Federation, which are implemented in the regions of the Russian Federation. 


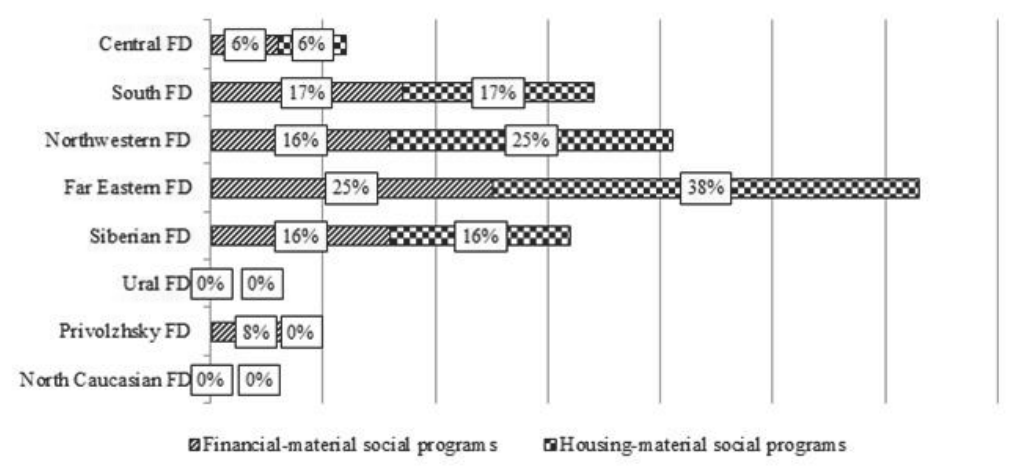

Figure 3. Social programs focused on attracting graduates of institutions of secondary vocational and higher education into the general education system of the Russian Federation, which are implemented in the Federal Districts of the Russian Federation.

Figure 3 shows, that the most active in the implementation of social programs aimed at attracting graduates of educational institutions of secondary vocational and higher education into the general education system is the Far Eastern Federal District (25\% of the regions are implementing social financial-material programs, $38 \%$ are implementing housing-material programs). Good performance for this type of work is detected in the following federal districts: the Northwestern (16\% of the regions e implementing social financial-material programs, $25 \%$ are implementing housingmaterial programs), the South (17\% and $17 \%$, respectively) and Siberian (16\% and $16 \%$, respectively). These social programs are rather poorly represented in the Central (6\% and 6\%, respectively) and Privolzhsky (8\% and $0 \%$, respectively) Federal Districts. Such social programs are not declared at all in the Ural and North Caucasian Federal Districts.

\section{Discussion}

Job rotation, as already noted, is a new phenomenon for the general education system of the Russian Federation. The presented statistical results confirm this statement, because the attempts to implement individual components of the technology of job rotation in the general education system are clearly detected; however, the work in the regions of the Russian Federation is not always systematic.

This issue is discussed in scientific publications. The presented key statements are expressed by Russian scientists on the subject of the appropriateness of the technology of job rotation in general education, as well as the features of the implementation of this personnel technology.

Ushakov in his article "Rotation, or fantasia on the personnel theme" justifies the need for rotation of successful managers of educational institutions, based on the fact that the experience of effective school management is very difficult to replicate, and only the author of this experience can transmit it. In this context, Ushakov considers school principals with experience of effective management as crisis managers in the general education system. Of course, according to the author, the body of the operative personnel reserve should consist of heads of educational institutions on a voluntary basis. As a method of attracting school principals to the operational reserve, the author considers financial incentives and special conditions of contract modalities: allocation of additional resources; mitigation of reporting requirements within a specified period; a special contract with guarantees in case of failure (Ushakov, 2010).

It should be noted that the reaction of the scientific and educational community to this idea was far from unambiguous.

Some researchers have disproved the fact of impossibility to replicate the successful experience of management. In particular, Kovalevsky the consultant of the Social Development Division of the Socioeconomic Development Department in the Administration of the Head of the Republic of Karelia, believes that "all effective management systems are isomorphic (the same in their essence)," and replication is unsuccessful only if the form is copied, but not the content, and also the creative transformation of an effective management model is not carried out. Therefore, the author offers not the rotation of successful managers, but joining "unsuccessful" schools to more successful ones as branches (Discussion 
of the publication Ushakov K.M., 2010).

It is also suggested that the transfer of personnel technologies from the business sector into the public sphere is very doubtful. Kuznetsova A.G., Doctor of Pedagogical Science, Rector of the Regional State Educational Institution of Additional Vocational Training "Khabarovsk Regional Institute of Education Development," notes that "the mentality of a state employee does not operate business categories» (Discussion of the publication Ushakov K.M., 2010).

However, a number of researchers support the idea of a pedagogical staff rotation in the system of general education. Kasprzhak A.G., Candidate of Pedagogical Science, Honored Teacher of the Russian Federation, Rector of the Moscow High School of Social and Economic Sciences, believes that "change of jobs is now if not a norm, then the rule, the resource of growth." The author, analyzing the problem, tends to focus more on the rotation of young specialists in the general education than on the leaders, because, in his opinion, young people have the consciousness that allows flexible adaptation to the modern world, and act effectively in crises (Discussion of the publication Ushakov K.M., 2010).

Tanurkova (2014) vividly illustrated the problem of the pedagogical staff aging. On the example of evaluation of the personnel potential of the city of Tiraspol, the author demonstrated the relevance of this issue: "Out of 244 employees of the administration of educational institutions in the city, $41 \%$ were over the age of 50 years, of which $16.8 \%$ were pensioners. Among 68 heads of educational institutions, 35.5\% were at the age of 50-60 years, $9 \%$ were aged over 60 , and $16.2 \%$ managers were at the age of retirement."

Meanwhile, according to a survey conducted by Director of the Institute for the Development of Education of the National Research University - Higher School of Economics Abankina I.V., due to the lack of clear, transparent mechanisms for job rotation in the general education system, the access to work in the school for graduates is very limited: "The project was attended by seventeen countries: the USA, Canada, Germany, Poland, Italy, Georgia, Norway, Finland, Taiwan, Singapore, South Korea, Philippines, Indonesia, and others. The respondents were graduates of pedagogical universities and those universities that issue the teacher diploma. 88 schools from Russia participated in the project-all 73 pedagogical and 15 classic Universities. As a result, in high school, our country ranked second both by knowledge of the subject and teaching methods as well. We have very motivated graduates who want to work with the students. But, unfortunately, only $20 \%$ of respondents hope actually to get a place in the school, and in fact, only $5 \%$ percent succeed. In other countries, such as Norway, which was in the middle of the list, $75 \%$ of graduates of pedagogical universities manage to get the jobs by specialty. It turns out that we prepare almost the world best teachers of mathematics (a third-fourth place in primary school) and they have nowhere to work. Later a similar study of working teachers was conducted, and it appeared that our position is twice as worse. That is the Russian teachers are actually not competitive. Currently, there are no international comparisons in other subjects. This study was conducted for the first time. Only at the end of last year, all countries have received these results. But they are very revealing. I.e. the problem is not related to the pedagogical universities, but to the educational system, in which there is no job rotation and there are no opportunities for young professionals" (Muravieva, 2011).

The authors of this study concur with the above-mentioned positions: the general education of the Russian Federation is in need of a transparent, consistent personnel policy; the rejection of declarative implementation of the technology of the personnel reserve formation and rotation is required. The data obtained by the authors and the personal experience of reservists testify on the declarative nature of the application of these technologies. Thus, L'dova in the article "Going to the personnel reserve," published in "Uchitel'skaia Gazeta", described the basic problems of personnel reserve creation consisting in the failure to abide by the original goals of this technology: the personnel reserve creation does not always lead to a real job rotation in the general education system of the Russian Federation. In particular, let us illustrate this statement by the words of L'dova: "We are about to meet 2014, but the personnel portal contains information of the year 2012. On the website of the Moscow Center for Quality of Education at June 27, 2013, there was an open invitation to pass qualification tests for the position of a "head of a state educational institution" (upon the recommendation of the employer or the application of the self-nominated person). It was only necessary to register in the database of candidates and submit an application. There were multiple fulfilled and non-fulfilled tasks between the 2012 and 2013, some officials responsible for it left the education system, new goals were formulated, and new reservists were recruited. But what happened to those 800 reservists who submitted their CVs in the fall of 2012 and were being tested for a whole year? Only few of them were nominated to leading positions, though all those people believed in the new beginnings and were motivated by the demand for their initiatives in the education system!" (L'dova, 2013).

\section{Conclusion}

Thus, the need to implement the job rotation technology in the general education system of the Russian Federation is not only a requirement of time, but also the need of a system that strives for development. However, the complexity of the 
implementation of modern personnel policy in general education consists in the abandonment of traditional practices to declare a certain mechanism, in the rejection of a formal approach to working with the staff. The study found that the most promising model of the personnel policy in the general education system of the Russian Federation is the consistent application of the technologies of the personnel reserve formation and job rotation. The stages of implementation of the model of personnel policy are as follows: (1) conducting an open tender for the inclusion in the personnel reserve of heads of educational institutions (pre-school and general education); (2) formation of the personnel reserve by regional and municipal executive authorities in the sphere of education; (3) implementation of the well-planned work with the personnel reserve; (4) rotation of the pedagogical staff according to the developed rotary strategy. The main types of job rotation, which can be fulfilled in the management of the education system of the Russian Federation, are considered rotation of heads of general educational institutions; vertical, horizontal rotation of pedagogical staff; rotation of young specialists and graduates of institutions of secondary vocational and higher education.

\section{Acknoeledgements}

The study was carried out within the framework of implementation of the scientific and methodical works included in the state order of the Ministry of Education and Science of the Russian Federation in 2015.

\section{References}

Bets, G., Brayndli, B., Williams, S. et al. (1998). Biznes. Tolkovyi slovar'. [Business. Dictionary] (Osadchaia I.M., Ed.). Moscow: "INFRAM", Izdatelstvo "Ves' Mir" [in Russian].

Black, S.E., Lynch, L.M., \& Krivelyova, A. (2004). How Workers Fare When Employers Innovate. Industrial Relations. Journal of Economy \& Society, 43(1), 44-66.

Chechel, I.D. (2014). Formirovanie upravlencheskogo rezerva dlia obshcheobrazovatelnykh organizatsii [Formation of the management reserve for educational institutions]. Upravlenie obrazovaniem: teoriia i praktika - Education Management: Theory and Practice, 1, 105-119 [in Russian].

Dmitriev, D.A. (2012). Osnovnye faktory innovatsionnogo razvitiia kadrovogo potentsiala rukovoditelei munitsipalnoi sistemy obrazovaniia [The main factors of innovative human resource development of managers in municipal education system]. Vektor nauki TGU - Vector of Science TGU], 1(8), 135-138. [in Russian].

Hsieh, A. \& Chao, H. (2004). A reassessment of the relationship between job specialization, job rotation and job burnout: Example of Taiwan's high-technology industry. International Journal of Human Resource Management, 15(6), 1108-1123.

Jaturanonda, C., Nanthavanij, S., \& Chongphaisal, P. (2006). A survey study on weights of decision criteria for job rotation in Thailand. International Journal of Human Resource Management, 17(10), 1834-1851.

Kibanova, A.la. (Ed.) (2010). Upravlenie personalom organizatsii [Organization Human Resource Management]. Moscow: INFRA-M [in Russian].

L'dova, A. (2013). Khozhdenie v kadrovyi rezerv [Going to the personnel reserve]. UG Moskva -Teacher's Newspaper. Moscow, 52. Retrieved from: http://www.ug.ru [in Russian].

Muravieva, M. (2011). Shkolam ne nuzhny uchitelia. Interviu s direktorom Instituta razvitiia obrazovaniia NIU-VShE Irinoi Abankinoi. [Schools do not need teachers. Interview with Director of the Institute for Educational Development HSE Irina Abankina]. Nauka $i$ tehnologii RF - Science and Technology of the Russian Federation. Retrieved from http://www.strf.rul [in Russian].

Obsuzhdenie publikatsii K.M. Ushakova "Rotatsiia, ili Fantazii na kadrovuiu temu" [Discussion of the Publication of Ushakov, K.M. "Rotation or Fantasia on the personnel theme"] (2010). Zhurnal rukovoditelya upravleniya obrazovaniem - Journal of Chief of the Department of Education, 5. Retrieved from: http://obr.direktor.ru/archive/2010/5/Rotatsiya_ili_Fantazii_na_kadrovuyu_temu [in Russian].

Ortega, J. (2001). Job rotation as a learning mechanism. Management Science. 47(10), 1361-1370.

Sardarian, A., \& Chernova, V. (2009). Kadrovye migratsii [Personnel Migration]. Upravlenie personalom - Personnel Management, 12 [in Russian].

Schultz, D., \& Schultz, S.E. (2010). Psychology and Work Today. Boston: Pearson

Tanurkova, E.I. (2014). Podgotovka rezerva rukovodyaschih kadrov. Iz opyta raboty MU UNO g. Tiraspolia [Preparation of the managerial personnel reserve. Experience of MU UNO, Tiraspol]. Zhurnal rukovoditelia upravleniia obrazovaniem - Journal of Chief of the Department of Education, 6 [in Russian].

Ushakov, K.M. (2010). Rotatsiia, ili Fantazii na kadrovuiu temu" [Rotation or Fantasia on the personnel theme]. Zhurnal rukovoditelya upravleniya obrazovaniem - Journal of Chief of the Department of Education, 5 [in Russian]. 